\title{
An Assessment of External Price Competitiveness for the Gambia
}

\author{
Tamsir Cham \\ Correspondence: Islamic Research and Training Institute, Islamic Development Bank., P.O.Box 9201 Jeddah, Kingdom
} of Saudi Arabia.

Received: August 11, 2016

Accepted: August 17, 2016

Available online: October 13, 2016

doi:10.11114/aef.v3i4.1799

URL: http://dx.doi.org/10.11114/aef.v3i4.1799

\begin{abstract}
This paper assesses The Gambia's competitiveness. A variety of econometrics techniques and survey based indicators suggest that recently, The Gambia has lost its competitiveness compared to the comparator countries. The econometrics techniques employed shows that the dalasi appreciated by 3 to 6 percentage points in real terms. However, these rates are broadly inline with fundamentals and there is zero misalignment. Survey based indicators suggested that The Gambia lagged behind in access to credit, tax rates, and protect investors and national work ethnics. The Gambian authorities need to implement serious reform on tax policies; introduce legislation to promote public private partnership and revamp the public sector.
\end{abstract}

Keywords: exchange rate, external price, doing business, global competitiveness index

\section{Introduction}

Exchange rate assessment is among the core mandates of the International Monetary Fund as a gauge to a country's competitiveness. A large amount of research has been undertaken on this issue, such as the Consultative Group on Exchange Rates (CGER) study of 54 countries, Aydin (2010), Vitek (2009), Lee et al (2008).

This paper assesses The Gambia's external competitiveness by applying four methodologies to evaluate the country's exchange rate level relative to its fundamentals. These include the macroeconomic balance (MB), equilibrium real exchange rate (ERER), purchasing power parity (PPP), and external sustainability (ES). In the MB method, the degree of overvaluation or undervaluation depends on the difference between the underlying current account balance and the current account norm, and also on the elasticity of current account with respect to the real exchange rate.

Under ERER methodology, the degree of overvaluation or undervaluation depends on both real and monetary fundamentals. Undervaluation or overvaluation is estimated by how much the actual real exchange rate deviates from the equilibrium real exchange rate.

Under the PPP method, the degree of disequilibrium is the difference between the actual observed value of the real effective exchange rate and its assessed long run equilibrium value.

Applying the ES method, a current account norm that will ease the net foreign assets of the country is calculated. Like in the macroeconomic balance methodology, the degree of disequilibrium depends on how much the current account norm deviates from the underlying current account and on the elasticity of the current account with respect to the real exchange rate.

With the aim of enhancing the empirical assessment, we broadened the analysis by cross-country comparisons using indicators from the World Bank's (WB's) Doing Business Report and World Economic Forum (WEF) Global Competitiveness Report. This paper is structured in the following. Section I deals with introduction, while Methodology and results are discussed in section II. While survey based indicators are examined in section III, conclusion and policy recommendations are discussed in section $\mathrm{V}$.

\section{Methodology and Empirical Results}

\subsection{Macroeconomic Balance Method}

Under the MB, we computed the undervaluation or overvaluation of the exchange rate required to close the gap between the current account norm, which is in line with the sustainable medium-term macroeconomic fundamentals of the country and the projected medium-term current account at the existing real effective exchange rate (REER). The extent of exchange rate disequilibrium is the percentage change in the real effective exchange rate necessary to balance the 
underlying current account with the current account norm. We followed Aydin (2010) to compute the current account norm using the following regression model:

$$
C A B_{i, t}=\alpha_{i}+\beta X_{i, t}+\varepsilon_{i, t}
$$

Where:

$C A B=$ Ration of the current account balance to output for economy $i$ at time $t, X_{i, t}=$ A vector of explanatory variables

Numerous research papers in these areas have provided the basis for the determinants of current account balance. The definition of the variables and their influence on current account are discussed below:

Fiscal balance, measured as the ratio of government budget balance to gross domestic product, tends to have a direct relationship between fiscal balance and current account balances provided national saving is not offset by private saving. A higher government budget balance raises both national saving and the current account balance. The "old population ratio" is used to capture the ratio of the dependent population in a country. A dependency ratio tends to decrease savings and the current account balance. Relative capital and per capita growth are used as proxies for economic development. All things being equal, a country with a higher income per capita is likely to invest more and hence will have a higher current account balance. Therefore we expect a positive relation between remittances and current account balance. Remittance inflow tends to positively impact small and low income economies. The impact of aid flows on the current account balance depends on its composition and its effect on tradable and nontradable sectors. There also tends to be positive association between net foreign assets (NFA) and the current account provided that a country with a large NFA will be in a position to attract larger inflow of capital.

We followed Lee et al (2008), Vitek(2009) and Aydin (2010) in modeling the current account. While the current account norm is derived from estimating the regression model using the explanatory variables, the underlying current account balance is the 2016 current account projection, reported in the April 2011 World Economic Outlook (WEO) database.

In the macroeconomic balance method, we estimate the regression model using the Generalized Method of Moments (GMM) taking into consideration heteroskedasticity on a data set consisting of 182 countries over the period 1973-2015. The data source used is from IMF International Finance Statistics database. In order to address the endogeneity problem, lagged explanatory variables are used as instruments. The estimated results are reported in Table 1 and Table 2.

Table 1. Estimation Results for the Macroeconomic Balance Method (The World)

\begin{tabular}{lll}
\hline Dependent variables: & Unrestricted & Restricted \\
\hline Relative old age dependency & $-00013^{* * *}$ & $-0.0014 * * *$ \\
Relative population growth & 0.0003 & $\ldots \ldots$ \\
Relative income & $0.0079^{*}$ & $0.0121^{* * *}$ \\
Relative Income growth & -0.0003 & $\ldots$. \\
Oil trade balance & $0.3672^{* * *}$ & $0.3787^{* * *}$ \\
Relative fiscal balance & $0.0004^{* * *}$ & $0.0006^{* * *}$ \\
Initial net foreign assets & $0.0208^{* * *}$ & $0.0373^{* * *}$ \\
Aid inflows & $-1.59 \mathrm{E}-10^{* * *}$ & $-1.17 \mathrm{E}-10^{* * *}$ \\
Remittance inflows & $-5.40 \mathrm{E}-12$ & $\ldots$. \\
$R$ Squared & 0.36 & 0.44 \\
\hline
\end{tabular}

$* * *, * * *$ denote $1,5,10$ percent level of statistical significant respectively

Our results collaborated with earlier studies by Lee et al (2008) and Vitek (2009). To the greater extent, current account balance is considerably influenced by the explanatory variables that were well thought-out by Lee et al (2008), Aydin (2010) and Vitek (2009). Coefficient estimates for the world and The Gambia are quite similar to those of the CGER, Aydin (2010) and Vitek (2009) in signs. 
Table 2. Estimation Results for the Macroeconomic Balance Method (Gambia data)

\begin{tabular}{lll}
\hline Dependent variables: & Unrestricted & Restricted \\
\hline Relative old age dependency & -0.0043 & $-0.0075^{*}$ \\
Relative population growth & 0.0033 & 0.0057 \\
Lag (CAB/GDP) & $\ldots .$. & $0.2389 * * *$ \\
Relative income & $-0.0502^{*}$ & -0.0222 \\
Relative Income growth & $1.31 \mathrm{E}-05$ & 0.0003 \\
Oil trade balance & $0.9056^{*}$ & 0.5231 \\
Relative fiscal balance & 0.163 & $0.1220 *$ \\
Aid inflows & $5.88 \mathrm{E}-11$ & $3.68 \mathrm{E}-11$ \\
$R$ Squared & 0.44 & 0.73 \\
\hline
\end{tabular}

$* * *, * * *$ denote $1,5,10$ percent level of statistical significant respectively

As expected, population dependency have negative sign and statistically significant. Relative income, oil trade balance, fiscal balance and aid flow show positive signs as expected. In addition the Gambian data with fixed effect, old age dependency, current account balance lag, and fiscal balance did not only show the right signs but are statistically significant.

We follow Aydin (2010) and Isard and Faruqi (1998) to calculate the elasticity of the current account balance with respect to the real exchange rate by using the following assumptions: imports elasticity (0.92) and exports elasticity (-0.71). For The Gambia we followed Aydin (2010) and set the export-output and import-output ratios to 0.29 and 0.40 respectively. Applying the macroeconomic balance approach with the above parameters to The Gambia indicates that the dalasi is appreciated by 17 percent in real effective terms. The appreciation is based on an estimated current account norm $^{1}$ of -2 percentage of output as compared to an underlying current account balance estimate of around -12 percent of output. We compute the underlying current account balance by taking the average of three values: the 2010 actual, the World Economic Outlook (WEO) forecast for 2016, and a 5-year moving average from 2003 to 2011.

\subsection{The Equilibrium Real Exchange Rate Method}

In the equilibrium real exchange rate method, we follow Edward (1989), Elbadwi and Soto (1997), Hinkle and Montiel (1999), Hallerberg (2002) and Cham (2010) and employ the concept of intertemporal model of the determinants of RER. Using this framework as a guide will help us separate the effects of short and long run determinants of RER and compute the equilibrium real exchange rate (ERER). The degree of exchange rate misalignment is the percentage difference between the actual value and the estimated equilibrium value. We followed Edward (1989) and others and use a single regression model as our empirical framework. We estimate below the linear equation:

$$
\begin{aligned}
& \log v=\alpha_{0}+\beta_{1} \log T O T+\beta_{2} \log \text { Open }+\beta_{3} \log \text { Govt }+\beta_{4} \log r G D P \\
& +\gamma_{1} \log m 2 G D P+\gamma_{2} \log \text { inf }+\gamma_{3} \log N E R+\varepsilon
\end{aligned}
$$

Where:

$\mathrm{v}=$ The real effective exchange rate (REER) is the dependent variable and the real determinants include the terms of

rGDP $=$ Real Gross Domestic Product

TOT $=$ Terms of trade

Open $=$ Openness measured as exports plus imports divided by GDP

Gov $=$ Government spending dived by GDP(Open)

m2GDP = Money supply percent of Gross Domestic Product

inf $=$ Rate of inflation

NER $=$ Nominal exchange rate

While real derminants are TOT, openness and government spending, nominal determinants of the RER include the

\footnotetext{
1 The coefficient estimates from Lee et al (2008), Vitek (2009), Aydin (2010), and the GMM estimates are applied to The Gambia data to compute the current account norm - the average of the four estimates is used as the current account norm (-2 percent of GDP).
} 
money supply as a ratio of GDP (m2GDP), average annual rate of inflation (inf), and the nominal exchange rate (NER) against the US dollar. The vector coefficients for the real or "permanent" and "transitory" components are $\beta=\left(\beta_{1}+\beta_{2}+\beta_{3}+\beta_{4}\right)$ and $\gamma=\left(\gamma_{1}+\gamma_{2}+\gamma_{3}\right)$ respectively. The sum of the real and transitory variables measures the degree at which they influence the NEER.

According to economic theory, an increase in the TOT is expected to appreciate the real exchange rate. Thus, an enhanced terms of trade could result to an appreciation of the real exchange rate and increase in income. The increase in flow of foreign exchange due to a favorable terms of trade may appreciate the local currency. Similarly an increase in government consumption is expected to appreciate the real exchange rate provided that such consumption falls more on nontradables than tradables. According to Edward (1989), openness may lead to some extent a lower domestic prices and may lead to a depreciation of the real exchange rate. According to Melvin and Bernstrin (1984) openness will positively affect the real exchange rate. All things being equal, a more variable domestic rate of inflation can result to higher exchange rate variability. Productivity could result to a real appreciation of the real exchange rate. If the productivity in tradables was growing faster than in non-tradables, the demand for higher wages will put pressure on wages in the non-tradables sector thereby putting an upward pressure on real exchange rate.

In estimating REER, we use data set which ranges from 1981- 2010. The data source for macroeconomic variables are from IMF International Finance Statistics (IFS) and Direction of Trade Statistics (DOT). We first estimate the single equation using OLS with one $\mathrm{lag}^{2}$. The regression results for the straight line method is reported in Table 3. The results obtained are quite intuitive. It is found that real factors have an significant role in determining the long-lasting real exchange rate even in the presence of monetary shocks. While the coefficients for TOT, government consumption are positive, openness and real GDP growth show a negative sign.

Table 3. Reduced form Equation

\begin{tabular}{lllll}
\hline Variable & Coefficient & Std. Error & t-Statistic & Prob. \\
\hline C & 5.059509 & 0.820332 & 6.167635 & 0 \\
LTOT(-1) & 0.236781 & 0.21566 & 1.097936 & 0.2836 \\
LGDP(-1) & -0.839612 & 0.649491 & -1.292722 & 0.2089 \\
LOPEN(-1) & -0.658885 & 0.235468 & -2.798198 & 0.0102 \\
LGOV(-1) & 0.65184 & 0.17449 & 3.735675 & 0.0011 \\
LINF(-1) & -0.130552 & 0.038473 & -3.393366 & 0.0025 \\
LMON(-1) & -0.024528 & 0.036492 & -0.672142 & 0.5082 \\
R-squared & 0.780609 & Mean dependent var & & 4.562677 \\
Adjusted $R$-squared & 0.723376 & S.D. dependent var & & 0.313817 \\
S.E. of regression & 0.165052 & Akaike info criterion & & -0.564148 \\
Sum squared resid & 0.626571 & Schwarz criterion & & -0.237202 \\
Log likelihood & 15.46221 & Hannan-Quinn criter. & & -0.459555 \\
F-statistic & 13.63926 & Durbin-Watson stat & & 1.052993 \\
Prob(F-statistic) & 0.000001 & & & \\
**, * denote 1, 5, 10 percent level of statistical significant respectively & & \\
\hline
\end{tabular}

As expected an increase in domestic inflation with others things been equal leads to an appreciation of the real effective exchange rate. All things remain equal, a surge in domestic monetary supply will lead to a depreciation of a currency. The estimation results indicate that the dalasi is primarily influenced by changes in the terms of trade, government spendings, openness, and relative productivity. Using the equilibrium real exchange rate approach with the above measurement method indicates that the dalasi is overvalued by 3 percent.

We also employed Vector Error Correction Model (VECM) to estimate REER because the series are non-stationary in levels but stationary in first differences and a co-integrating vector is present, based on both the trace and the maximum eigenvalue statistics. Table 4 shows the details of the Johansen maximum likelihood cointegration test. From the VECM results, the dalasi appreciated by 6 percent.

Table 4. Co-integration

\footnotetext{
${ }^{2}$ We conducted a unit root test and found out that all variables are stationary at first differences.
} 


\begin{tabular}{lcccc}
\hline Hypothesized & \multicolumn{5}{c}{ Trace } & 0.05 & Critical Value & Prob.** \\
No. of CE(s) & Eigenvalue & Statistic & 125.6154 & 0.0000 \\
\hline None $*$ & 0.867502 & 233.4095 & 95.75366 & 0.0000 \\
At most $1 *$ & 0.822932 & 168.7315 & 69.81889 & 0.0000 \\
At most $2^{*}$ & 0.682863 & 113.3325 & 47.85613 & 0.0000 \\
At most $3 *$ & 0.629724 & 76.58294 & 29.79707 & 0.0005 \\
At most $4 *$ & 0.565504 & 44.79076 & 15.49471 & 0.0197 \\
At most 5* & 0.367455 & 18.11659 & 3.841466 & 0.0628 \\
At most 6 & 0.102497 & 3.460458 & & \\
\hline
\end{tabular}

2.3 The External Sustainability Method

The external sustainability method is similar to the MB approach but differs in the computation of current account norm. In the ES methodology, the current account norm is calculated as the current account to GDP ratio that even out NFA at some standard level. In this methodology, we follow Aydin (2010) and calculate the current account norm with the following equation:

$$
C A B_{i}^{n}=\frac{g_{t}}{1+g_{t}} N F A_{i}^{n}
$$

Where:

$C A B=$ Current account norm for country $i, N F A=$ The norm value of the country's net foreign assets as percent of Gross Domestic Product, and $g=$ The country's GDP growth rate.

Applying equation (3) to The Gambia indicates the dalasi appreciated by 4.0 percentage point in real term. The appreciation is based on -12.7 percent of output as net foreign asset norm. This indicates an assessed current account norm of -9.7 percent of output as compared to an underlying current account balance estimate of -12.2 percent of output. As in the macroeconomic approach, an elasticity of -0.57 is computed by assuming import elasticity of 0.92 and export elasticity of -0.71 .

\subsection{Purchasing Power Parity Approach}

With the Purchasing Power Parity (PPP) methodology, we used Levin, Chu (2002), Im, Pesaran and Shin (2003), Vitek (2009) and assume that relative purchasing power parity holds in the long run and logarithm of the real effective exchange rate is stationary. Under the PPP estimation method, the long run equilibrium value of the logarithm of the real effective exchange rate is assessed by its sample mean. However, given that RERs of fast-growing developing countries tend to appreciate over time, we first compute a time trend and compute the fitted value. The degree of exchange rate misalignment is the difference between the fitted value and the long run equilibrium. With the PPP estimation The Gambia dalasi appreciated by 3 percent point. Data is sourced from International Monetary Fund International Finance Statistics database.

While external sustainability estimate revealed the dalasi appreciated by 4.0 percentage point in real term, the PPP method showed the dalasi appreciated by 3 percent point. A summary of the exchange rate assements results from various methods is presented in table 5 .

Table 5. The Gambia: Summary of Exchange Rate Assessment Results

\begin{tabular}{ll}
\hline Methodology & $\begin{array}{l}\text { Valuation (in percent) Over (+) or } \\
\text { Under (-) }\end{array}$ \\
\hline Macroeconomic Balance & 17 \\
External Sustainability & 4 \\
Purchasing Power Parity & 3 \\
Balance of Payment Flows & 0 \\
Equilibrium Real Exchange Rate: & \\
$\quad$ VECM Model & 6 \\
Average OLS Model & 3 \\
\hline Sorce & $\mathbf{5 . 5}$ \\
\hline
\end{tabular}

Source: IMF and author's calculation

In conclusion, we take the average of the four approach to concluded that the dalasis is overvalued by 5.5 percent. For robustness check we use survey based indicators.

\section{Survey Based Indicators}

In order to complement our econometric findings in the real exchange rate, this section examines survey based indicators from the World Bank's Doing Business Indicators and the World Economic Forum's Global Competitiveness Index. 


\subsection{The Doing Business Indicators}

From the World Bank's Doing Business Indicators, The Gambia is ranked at the bottom 20 percent of the economies. The Gambia ranked 146 out of 183 countries in the 2011 survey and 141 out of 183 in the 2010 survey. The Gambia ranked best in enforcing contract (67) and worst in paying taxes, protecting investors (173), getting credit (138) and registering property and closing a business (121). While The Gambia ranked below par in the world, it's the fourth best in doing business in the West African Monetary Zone (WAMZ ${ }^{3}$ ) zone.

We sourced our data from World Bank 2011/2012 doing business indicators report. We consider three countries- Cape Verde, Benin and Senegal which are sighted as comparator countries for the following reasons: First, Cape Verde just like the Gambia depends on tourism as a source of foreign exchange. Second, Benin, similar to The Gambia is a hub for re-exports. As the The Gambia re-exports to neighboring countries like Senegal, Mali and Guinea-Bissau, so is Benin to Niger and Nigeria. Third, Senegal is The Gambia's immediate neighbor and has a lot in common. On the one hand, Cape Verde performed better than The Gambia, on the other hand, The Gambia performed better than Benin (see figure 1).

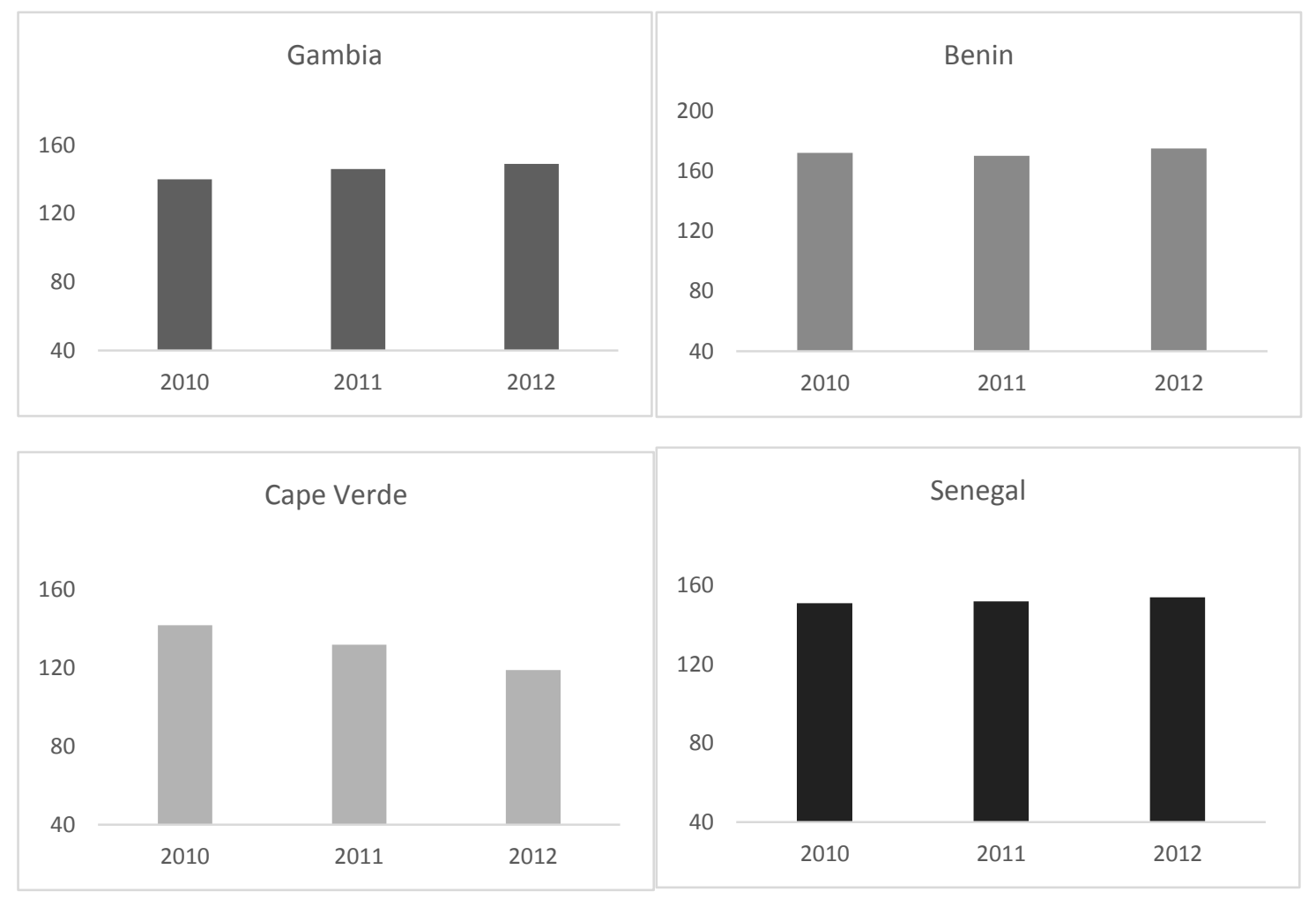

Figure 1. World Bank's Doing Business Indicators 2010, 2011, and 2012

Source: World Bank Forum's Global Competitiveness 2011/2012

Considering doing business performance year-on-year (2010- 2011), The Gambia is worst off compared to not only with Cape Verde, Benin and Senegal but with the entire zone. With exception of Ghana, all WAMZ member countries are worst-off in their performance in 2011 as compared to the previous year (see figure 2).

\footnotetext{
3 WAMZ members are Gambia, Ghana, Guinea, Libeia, Nigeria and Sierraleone
} 


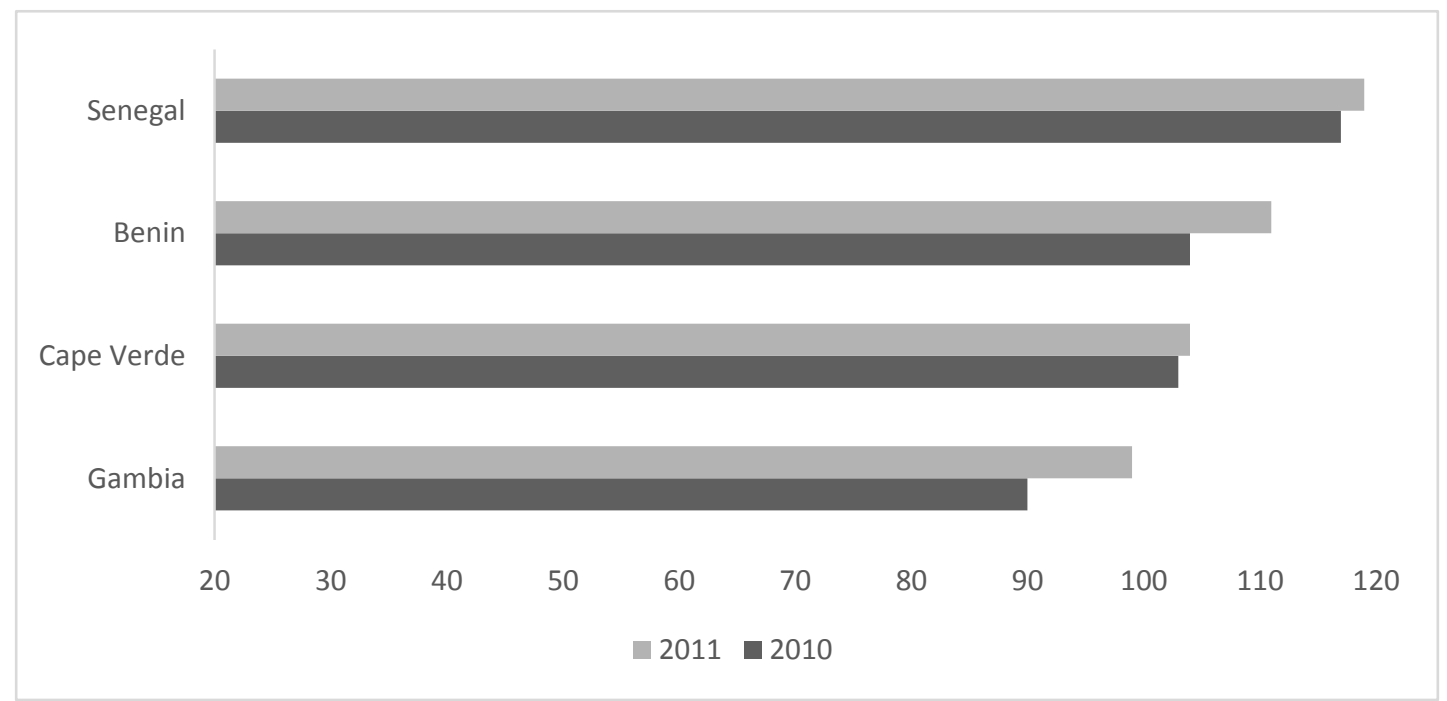

Figure 2. World Economic Forum Global Competitiveness Index (Out of 142 countries)

Source: World Bank Forum's Global Competitiveness 2011/2012

From table 6, The Gambia's overall ranking in Doing Business has deteriorated by 6 point. Unlike comparator countries, with the exception of Senegal whose overall ranking declined by 1, Cape Verde and Benin have shown an improvement of 10 and 2 respectively in the overall ranking.

Table 6. Doing Business Indicator

\begin{tabular}{|c|c|c|c|c|c|c|c|c|}
\hline \multirow{2}{*}{ Country \Ranking } & \multicolumn{2}{|c|}{ Gambia } & \multicolumn{2}{|c|}{ Cape Verde } & \multicolumn{2}{|c|}{ Benin } & \multicolumn{2}{|c|}{ Senegal } \\
\hline & 2010 & 2011 & 2010 & 2011 & 2010 & 2011 & 2010 & 2011 \\
\hline Overall Ranking & 140 & 146 & 142 & 132 & 172 & 170 & 151 & 152 \\
\hline Starting a Business & 114 & 115 & 139 & 120 & 154 & 157 & 102 & 101 \\
\hline Dealing with License & 79 & 80 & 84 & 89 & 134 & 125 & 119 & 117 \\
\hline Registering property & 117 & 121 & 131 & 104 & 128 & 129 & 167 & 167 \\
\hline Getting Credit & 135 & 138 & 150 & 152 & 150 & 152 & 150 & 152 \\
\hline Protecting Investors & 172 & 173 & 131 & 132 & 153 & 154 & 165 & 167 \\
\hline Paying Taxes & 176 & 176 & 143 & 100 & 166 & 167 & 171 & 170 \\
\hline Trading Across Borders & 81 & 87 & 52 & 55 & 128 & 127 & 61 & 67 \\
\hline Enforcing Contracts & 67 & 67 & 38 & 38 & 177 & 177 & 148 & 148 \\
\hline Closing a Business & 123 & 121 & 183 & 183 & 132 & 118 & 81 & 79 \\
\hline Number of countries & 183 & 183 & 183 & 183 & 183 & 183 & 183 & 183 \\
\hline
\end{tabular}

Source: World Bank Doing Business Indicators

Considering Doing Business Indicators components with the exception of closing a business, enforcing contracts and paying taxes where The Gambia improved by 2 and remained constant respectively in the ranking, The Gambia's ranking declined in all the other components. The Gambia performed worst in trading across borders, registering property and getting credit. Even though all the comparator countries have shown a decline in getting credit, the magnitude in The Gambia is greater.

\subsection{The World Forum's Global Competitiveness Index}

According to 2011- 2012 World Economic Forum's Global Competitiveness Index, The Gambia is placed 99 out of 142 countries for 2011. This shows a small drop from 90 out of 139 countries in the 2010 survey (see table 7). Despite The Gambia being ranked higher than comparator countries, overall ranking for The Gambia has declined by 9 while Senegal, Cape Verde and Benin have declined by 7, 2, and 1 respectively. 
Table 7. Global Competitiveness Index

\begin{tabular}{lllllllll}
\hline \multirow{2}{*}{ Country|Ranking } & \multicolumn{2}{c}{ Gambia } & \multicolumn{2}{c}{ Benin } & \multicolumn{2}{c}{ Cape Verde } & \multicolumn{2}{c}{ Senegal } \\
& $\mathbf{2 0 1 0}$ & $\mathbf{2 0 1 1}$ & $\mathbf{2 0 1 0}$ & $\mathbf{2 0 1 1}$ & $\mathbf{2 0 1 0}$ & $\mathbf{2 0 1 1}$ & $\mathbf{2 0 1 0}$ & $\mathbf{2 0 1 1}$ \\
\hline Overall ranking & 90 & 99 & 103 & 104 & 117 & 119 & 104 & 111 \\
Institutions & 37 & 38 & 87 & 92 & 56 & 54 & 76 & 78 \\
Infrastructure & 69 & 56 & 113 & 119 & 109 & 109 & 112 & 122 \\
Macroeconomic Stability & 117 & 99 & 82 & 58 & 102 & 102 & 89 & 89 \\
Health and primary education & 124 & 124 & 108 & 110 & 88 & 95 & 118 & 119 \\
Higher education and training & 103 & 115 & 112 & 111 & 109 & 102 & 110 & 110 \\
Goods market efficiency & 66 & 86 & 100 & 101 & 111 & 106 & 79 & 89 \\
Labor market efficiency & 16 & 32 & 85 & 63 & 122 & 124 & 109 & 99 \\
Financial market sophistication & 76 & 72 & 95 & 98 & 104 & 109 & 107 & 106 \\
Technological readiness & 97 & 77 & 122 & 119 & 79 & 81 & 93 & 86 \\
Market size & 138 & 139 & 124 & 123 & 139 & 142 & 105 & 105 \\
Business sophistication & 65 & 77 & 99 & 100 & 131 & 126 & 84 & 86 \\
Innovation & 62 & 62 & 60 & 67 & 117 & 119 & 55 & 53 \\
Number of countries & 139 & 142 & 139 & 142 & 139 & 142 & 139 & 142 \\
\hline Source Worl & & 149 &
\end{tabular}

Source: World Economic Forum's Global Competitiveness Index

The Gambia performed worst in Goods market efficiency, Labor market efficiency, Higher education and training and Business sophistication which show with a drop of 20,16,12 and 12 respectively as compared to the previous ranking. The most problematic areas for doing business in The Gambia include: lack of access to financing, high tax rates, poor work ethic in national labor force and complicated foreign currency regulations. On these scores, The Gambia performed poorly compared to Benin and Cape Verde (see figures 3 and 4).

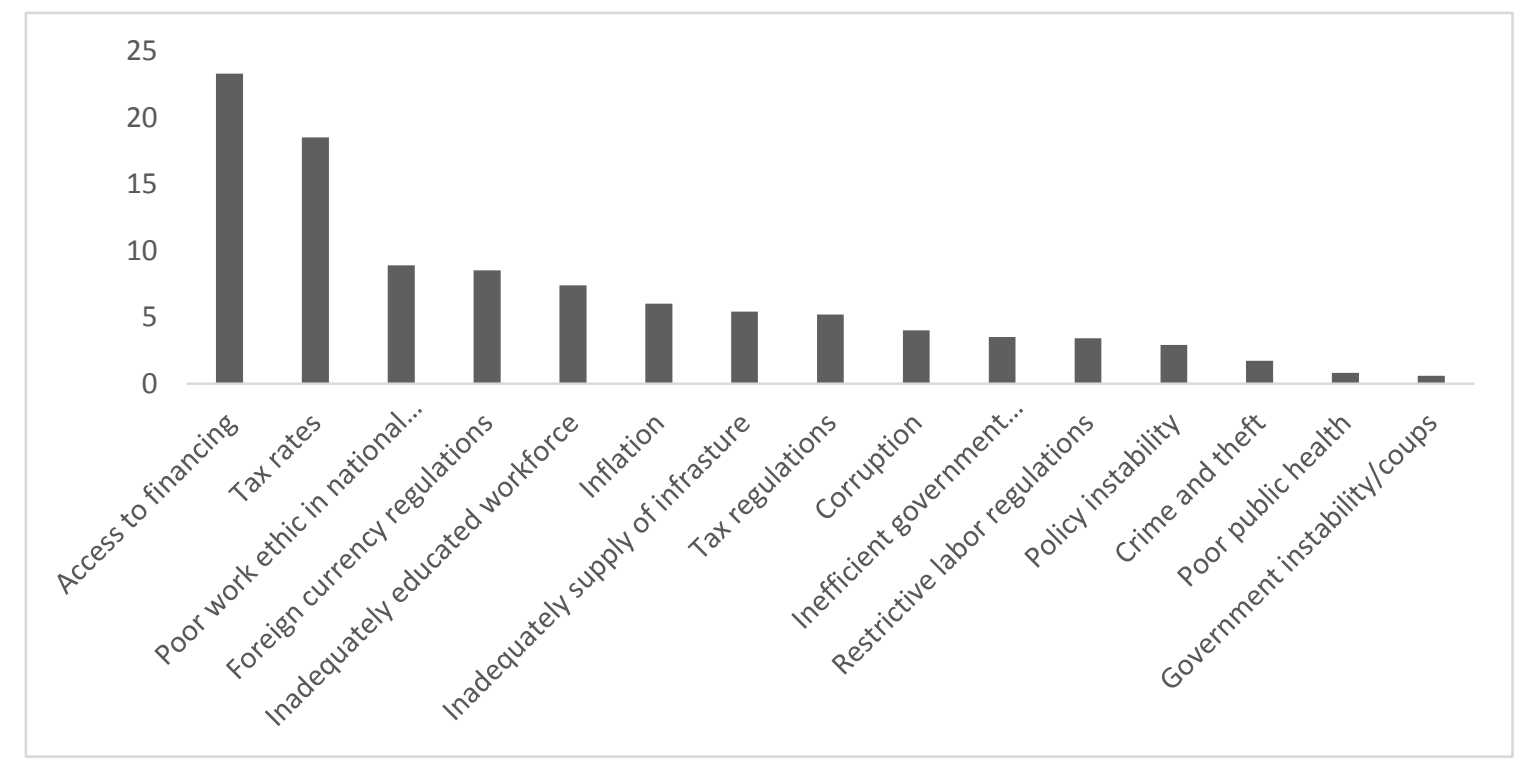

Figure 3. The Gambia- The Most Problematic Factors for Doing Business

Source: 2011/2012 World Bank doing Business Indicators 

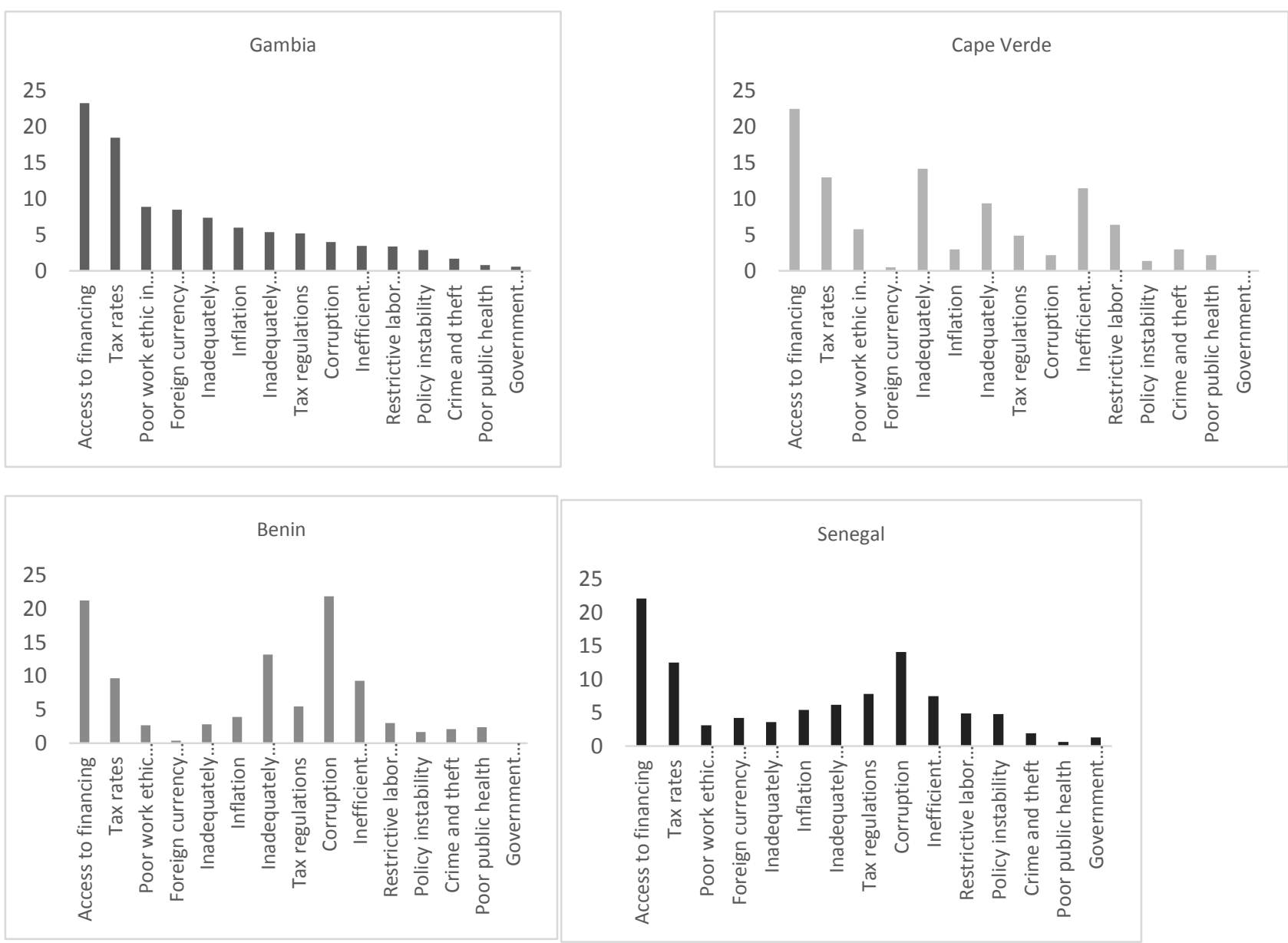

Figure 4. The Most Problematic Factors for Doing Business- Benin, and Cape Verde, Gambia and Senegal Source: 2011/2012 World Bank doing Business Indicators

\section{Conclusion and Policy Recommendations}

On average, our assessments indicate that the dalasi is overvalued by about $5^{1 /}{ }_{2}$ percent. This overvaluation is lower than the previous IMF exchange rate assessment. ${ }^{4}$ As in most low-income countries (LICs), data weaknesses and methodological uncertainties make it difficult to reach a definite conclusion. However, in light of the consistent agreement of the results from various methodologies, we established that the Gambia's exchange rate has appreciated slightly. This overvaluation of RER could affect trade competitiveness of The Gambia and consequently pose external vulnerability. In addition, an overvaluation of the currency makes the country's exports relatively expensive.

As recommended in the previous studies (see Slavov 2011), The Gambia needs to implement a more floating exchange rate regime rather than manage float and minimize tracking US dollar. It may consider pegging the dalasi towards basket of currencies. Between 2008 and 2010 when the dalasi was traded to the US dollar at a "natural rate", the dalasi became under pressure in 2010 apparently forced the CBG to intervened in the foreign exchange market. This led to loss of international reserves and investor confidence. Moreover, the dalasi following the US dollar increases its exchange rate volatility with other major international currencies such as the Euro and British Pound. Exchange rate volatility leads to uncertainty and misallocation of resources which adversely impact economic growth.

Since tourism and re-exports are the main source of foreign exchange earnings for The Gambia, the country needs to refocus its attention more towards the Euro and British Pound Sterling given that the majority of tourists come from the euro area. Furthermore, the main destinations of The Gambia's re-exports are Mali and Senegal whose currency, the CFA, is pegged to the Euro.

According to the World Bank's Doing Business Indicators ranking, The Gambia need to take major reforms, which

\footnotetext{
${ }^{4}$ See The Gambia: Staff Report for 2010 Article IV Consultation IMF country report No. 10/274

5 The natural rate referred to 27-27.5 dalasi to the US dollar
} 
among others include improving tax compliance, protecting investors, and broadening access to credit. From the World Economic Forum's Global Competitiveness Index, where The Gambia ranked 99 out of 142,the Gambian authorities need to improve on market size, healthcare, education and training system. In summary, major abstacles highlighted for doing business in which The Gambia performed poorest compared to comparator countries include access to finance, tax rate, poor work ethic in national work force and foreign currency regulations. It is therefore imperative for The Gambia to implement policies towards lowering lending rates, rationalizing and reducing tax rates, and allowing the dalasi to float freely against major currencies. There is a need for a major reform in tax policy, tax administration (tax compliance), investor protection, foreign exchange regulations and work ethics. There is also the need to introduce legislation to promote public private partnership and revamp the public sector reform.

\section{References}

Aydin, B. (2010). Exchange Rate Assessment for Sub-Saharan Economies. IMF Working Paper. http://dx.doi.org/10.5089/9781455201457.001

Cham, T. (2010). Real Exchange Rate Misalignment in WAMZ Countries. Journal of Economic Cooperation and Development, 31(4), 77-102.

Edwards, S. (1989). Real exchange rate variability: An Empirical Analysis of the developing country case. International Economic Journal, 1(1), 91-106. http://dx.doi.org/10.1080/10168738700080008

Elbadawi, I. A., \& Soto, R. (1997). Real Exchange Rates and Macroeconomic Adjustments in Sub-Saharan Africa and other Developing Countries. Journal of African Economics, 6, 1-56.

Hallerberg, E. W. (2002). Cost and Benefits of Monetary Union: A Study of The Franc Zone. PhD thesis, Emory University, Atlanta, Georgia.

Hinkle, L., \& Montiel, P. (1999). Exchange Rates Misalignment: Concepts and Measurement for Developing Countries. World Bank. Washington, DC.

Im, K. S., Pesaran, M. H., \& Shin, Y. (2003). Testing for unit roots in heterogeneous panels. Journal of Econometrics 115, 53-74. http://dx.doi.org/10.1016/S0304-4076(03)00092-7

Lee, J., Milesi-Ferretti, G., Ostry, J., Prati, A., \& Ricci, L. (2008). Exchange rate Assessments: CGER Methodologies. IMF Occasional Paper No. 261 (Washington: International Monetary Fund). http://dx.doi.org/10.5089/9781589066380.084

Levin, A., Lin, C. F., \& Chu, C. S. J. (2002). Unit root tests in panel data: Asymptotic and finite-sample properties. Journal of Econometrics, 108, 1-24. http://dx.doi.org/10.1016/S0304-4076(01)00098-7

Slavov, S. (2011). De Jure versus De Facto Exchange Rate Regimes in Sub-Saharan Africa. IMF Working Paper No. 198.

The Gambia: Staff Report (2010). Article IV Consultation IMF country report No. 10/274.

The Gambia: Staff Report(2011). Article IV Consultation IMF country report No. 12/17.

Vitek, F. (2009). An Assessment of External Price Competitiveness for Mozambique. IMF Working paper No. 165. http://dx.doi.org/10.5089/9781451873122.001

World Bank doing Business Indicators 2011/2012 report.

World Economic Forum's Global Competitiveness( 2011-2012).

World Economic Outlook (2011). database.

\section{(cc) $\mathrm{EY}$}

This work is licensed under a Creative Commons Attribution 3.0 License. 